\title{
Age and growth of longfinned eels (Anguilla dieffenbachii) in pastoral and forested streams in the Waikato River basin, and in two hydro- electric lakes in the North Island, New Zealand
}

\section{BENJAMIN L. CHISNALL ${ }^{1}$ \\ BRENDAN J. HICKS ${ }^{2}$}

Freshwater Fisheries Research Centre

Ministry of Agriculture and Fisheries

P.O. Box 6016

Rotorua, New Zealand

${ }^{1}$ Present address: NIWA-Ecosystems, National Institute of Water \& Atmospheric Research Ltd, Private Bag 3123, Hamilton, New Zealand

${ }^{2}$ Present address: Department of Biological Sciences, University of Waikato, Private Bag 3105, Hamilton, New Zealand

\begin{abstract}
Growth rates of New Zealand endemic longfinned eels (Anguilla dieffenbachii) from streams in pasture and indigenous forest, and from two hydroelectric lakes (Lakes Karapiro and Matahina), were estimated by otolith examination. Habitat-specific growth was further investigated with measurement of widths of annual bands in otoliths. Longfinned eels $170-1095 \mathrm{~mm}$ in length ranged between 4 and 60 years old $(N=252)$. Eels in pastoral streams grew faster (mean annual length increment $\pm 95 \% \mathrm{CL}=24$ $\pm 3 \mathrm{~mm}$ to $36 \pm 7 \mathrm{~mm}$ ) than eels in streams in indigenous forest (annual length increment $12 \pm 2$ $\mathrm{mm}$ to $15 \pm 3 \mathrm{~mm}$ ). Eels from the hydro-electric lakes had growth rates (annual length increments $19 \pm 4$ and $19 \pm 7 \mathrm{~mm}$ ) similar to eels from pastoral streams. Otoliths of most eels showed annual band widths that indicated growth in several different habitats, corresponding to growth during upstream migration, and limited movement among adult habitats. Estimated age at marketable size (220 g) ranged between 7 and 26 years. The particularly slow growth of longfinned eels in streams in indigenous forest has considerable implications for management. The fast growth rates of eels in hydro-electric lakes provides
\end{abstract}

\section{M92055}

Received 20 October 1992; accepted 9 June 1993 evidence for the potential of increased eel production by stocking. The probable selective production of female eels in these lakes may be nationally important to allow enhancement of breeding stocks.

Keywords Anguilla dieffenbachii; Anguilla australis; Anguillidae; age; growth; otoliths; growthband; pastoral; indigenous forest; hydro-electric lake; Waikato River basin; New Zealand

\section{INTRODUCTION}

The New Zealand commercial eel fishery exploits wild longfinned (Anguilla dieffenbachi Gray, 1842) and shortfinned eels (Anguilla australis Richardson, 1848). Longfinned eels are endemic to New Zealand, and constitute $42 \%$ of the average annual national catch, which fluctuates around $1200 \mathrm{t}$ (Ministry of Agriculture and Fisheries statistics). One of the most productive eel fisheries in New Zealand is in the Waikato River basin, where longfinned eels comprise up to $30 \%$ of the 150-200 t annual catch. Longfinned eels are found throughout the Waikato River catchment but are more abundant in the upper reaches of streams and rivers, and mainstem hydro-electric impoundments, than in lowland rivers, lakes, or wetlands (e.g., Chisnall 1989; Chisnall \& Hayes 1991; Swales \& West 1991).

Methods for studying growth rates of New Zealand eels have been established (Jellyman 1977, 1979; Todd 1980; Hu \& Todd 1981; Chisnall 1989; Chisnall \& Hayes 1991). Otoliths of both shortfinned and longfinned eels show alternating concentric transparent and opaque bands; each transparent zone delimits 1 year's growth. The width of opaque bands (growth bands), appears to be correlated with habitat type, as do growth rates (e.g., Chisnall 1989; Chisnall \& Hayes 1991). The main aims of the present paper were to determine to what extent growth rates of longfinned eels vary among habitat types, and to test objectively whether growth bands in the otoliths of longfinned eels have characteristic widths in different habitats. 


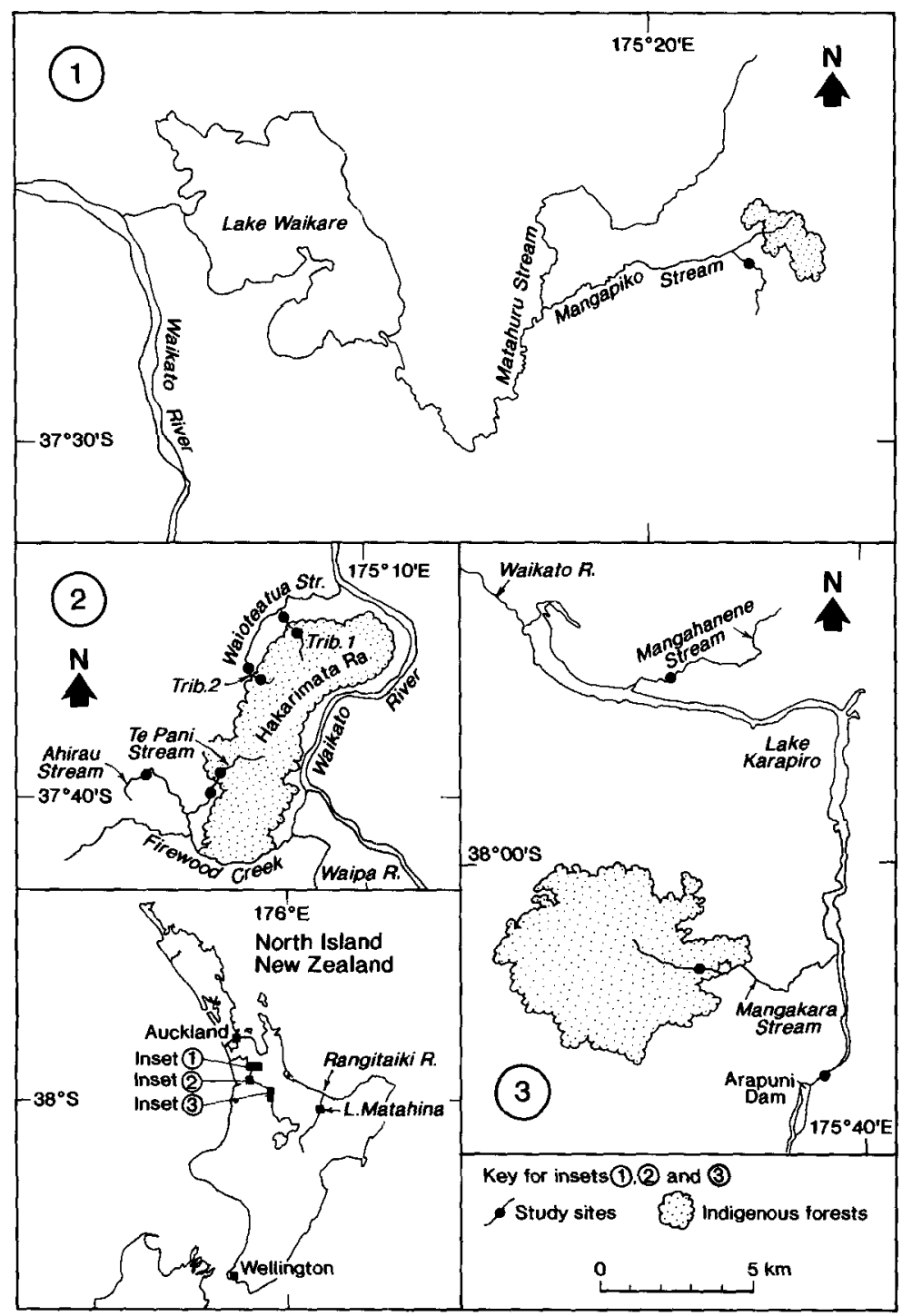

Fig. 1 Location of study sites in the Waikato River basin, and Rangitaiki River, North Island, New Zealand.

\section{STUDY SITES}

Stream study sites were located in tributaries of the lower Waikato River in the North Island, south of Auckland (Fig. 1), between $86 \mathrm{~km}$ and $175 \mathrm{~km}$ upstream from the sea (Table 1). Channel morphology and water temperature were measured for each stream site, and gradients were estimated from topographical maps (Table 1). Four study sites were in indigenous forest, and seven in pasture. Stream sites that had not been previously commercially fished (local knowledge) were chosen to ensure that eels sampled came from unexploited stocks. Commercial harvest has been shown to rapidly reduce the number of large eels in the population (e.g., Jellyman 1992).

In addition to the stream sites, eels were also collected from two hydro-electric impoundments: Lake Karapiro on the Waikato River, and Lake Matahina on the Rangitaiki River (Fig. 1). Lake Karapiro is an impoundment formed in 1947 above Karapiro dam, the lowest of nine dams on the Waikato River. The lake is $150 \mathrm{~km}$ upstream from the sea and has an area of $5.4 \mathrm{~km}^{2}$ (Strachan 1979; Livingston et al. 1986). During October and November 1989 the tailrace of Arapuni hydro-dam (immediately upstream of Lake Karapiro) was drained. An earth coffer-dam 
was constructed $1.5 \mathrm{~km}$ below the Arapuni dam, and the water was pumped out. Eels were collected for the present study from residual pools in this upstream end of Lake Karapiro (Boubée et al. 1989).

Lake Matahina is a hydro-electric impoundment on the Rangitaiki River that was formed in 1967 behind a $60-\mathrm{m}$ earth-core dam. The lake has an area of $2.5 \mathrm{~km}^{2}$ (Phillips \& Nelson 1981), and is $30 \mathrm{~km}$ upstream from the east coast of the North Island. Eels were collected for this study from Lake Matahina in April 1988 when the lake level was lowered to facilitate repairs to the dam.

\section{METHODS}

\section{Eel capture}

Eels were collected from stream sites using a combination of electric fishing to depletion (using a $90 \mathrm{~W}, 12 \mathrm{~V}$ back-pack machine, delivering pulsed DC current), and unbaited fyke nets set overnight (12 $\mathrm{mm}$ and $6 \mathrm{~mm}$ stretched mesh). Eels were removed from the drained section of Lake Karapiro with baited fyke nets set along the shorelines of residual pools that were 1-2 $m$ deep (Boubée et al. 1989). Lake Matahina was fished in a similar fashion in April 1988.

Tributary streams of the Waikato River were fished during March and April 1987, July and August
1988, and August 1989. Lake Karapiro was fished in November 1989, and its tributary streams in December 1989 and March 1990. Captured eels were measured in length and weighed whole to the nearest $\mathrm{mm}$ and $\mathrm{g}$, respectively, while fresh. Eels $<200 \mathrm{~mm}$ total length (TL) were inadequately sampled because of the mesh size of nets used, and the evasive behaviour of small eels when electro-shocking. Thus, few small eels were included in subsequent analysis.

\section{Growth determination and analysis}

The sagittal otoliths were extracted and prepared using the crack-and-burn method (Jellyman 1979). Otolith halves were mounted on microscope slides in silicone rubber sealant (Hu \& Todd 1981). Transparent zones (dark when burnt), were counted to determine age. Age was expressed as years spent in freshwater, ignoring the central zone of larval growth (Jellyman 1979).

To investigate the relationship between otolith growth-band width and habitat type, mounted otolith halves were selected for growth-band width measurement from several locations, representative of three main habitat types (pastoral and forested sections in the three Hakarimata Range streams, Mangakara and Mangahanene streams, and Lake Karapiro, $N=153$ ). Only otoliths that could be easily read and which had been cleanly axially fractured

Table 1 Environmental variables recorded from streams in the Waikato River basin. Gradients, distance from sea, and catchment areas measured from 1:50 000 topographical maps (NZMS 260); water temperatures measured in March 1990.

\begin{tabular}{|c|c|c|c|c|c|c|c|c|c|c|}
\hline \multirow[b]{2}{*}{ Location } & \multirow{2}{*}{$\begin{array}{c}\text { Distance } \\
\text { fished } \\
(\mathrm{m})\end{array}$} & \multirow{2}{*}{$\begin{array}{l}\text { Gradient } \\
\left(\mathrm{m} \mathrm{km}^{-1}\right)\end{array}$} & \multicolumn{3}{|c|}{$\begin{array}{c}\text { Proportions of } \\
\text { channel types (\%) }\end{array}$} & \multicolumn{2}{|c|}{ Pool dimensions } & \multirow{2}{*}{$\begin{array}{c}\text { Water } \\
\text { temperature } \\
\left({ }^{\circ} \mathrm{C}\right)\end{array}$} & \multirow{2}{*}{$\begin{array}{c}\text { Distance } \\
\text { upstream } \\
(\mathrm{km})\end{array}$} & \multirow{2}{*}{$\begin{array}{c}\text { Catchment } \\
\text { area } \\
\left(\mathrm{km}^{2}\right)\end{array}$} \\
\hline & & & Run & Riffle & Pool & $\begin{array}{l}\text { Width } \\
\text { (m) }\end{array}$ & $\begin{array}{c}\text { Depth } \\
\text { (m) }\end{array}$ & & & \\
\hline \multicolumn{11}{|l|}{ Lowland pasture } \\
\hline Mangahanene & 400 & 10 & 57 & 20 & 23 & 2.5 & 0.68 & 14.5 & 154 & 11.39 \\
\hline Ahirau & 400 & 25 & 66 & 15 & 21 & 1.4 & 0.45 & 14.5 & 100 & 1.44 \\
\hline \multirow{2}{*}{\multicolumn{11}{|c|}{$\begin{array}{l}\text { Pasture below forest } \\
\text { Hakarimata Ranges }\end{array}$}} \\
\hline & & & & & & & & & & \\
\hline Te Pani & 130 & 31 & 56 & 24 & 20 & 1.9 & 0.54 & 14.0 & 101 & 4.80 \\
\hline Waioteatua trib. 1 & 220 & 40 & 55 & 24 & 21 & 1.2 & 0.28 & 13.5 & 86 & 1.56 \\
\hline Waioteatua trib. 2 & 400 & 49 & 63 & 27 & 10 & 1.0 & 0.18 & 14 & 86 & 0.64 \\
\hline Mangapiko & 700 & 57 & 58 & 27 & 15 & 2.1 & 0.45 & 14.0 & 86 & 2.93 \\
\hline Mangakara & 200 & 60 & 59 & 27 & 14 & 2.0 & 0.35 & 13.0 & 175 & 4.84 \\
\hline \multirow{2}{*}{\multicolumn{11}{|c|}{$\begin{array}{l}\text { Indigenous forest } \\
\text { Hakarimata Ranges }\end{array}$}} \\
\hline & & & & & & & & & & \\
\hline Te Pani & 387 & 42 & 58 & 25 & 17 & 2.4 & 0.42 & 12.0 & 101 & 2.40 \\
\hline Waioteatua trib. 1 & 205 & 89 & 71 & 18 & 11 & 1.3 & 0.18 & 11.5 & 86 & 0.86 \\
\hline Waioteatua trib. 2 & 218 & 67 & 41 & 41 & 18 & 1.4 & 0.25 & 12.5 & 86 & 0.36 \\
\hline Mangakara & 1000 & 80 & 60 & 32 & 8 & 2.0 & 0.30 & 11.5 & 175 & 3.90 \\
\hline
\end{tabular}


across the central larval zone were used $(N=$ 74).

Widths of growth-bands were measured with a calibrated eyepiece graticule $(100 \mu \mathrm{m}=63.8$ graticule units, $S D=1.4$ ) under $80 \times$ magnification. Growth bands, determined as the distance between successive transparent zones, were individually measured beginning at the outer perimeter of each otolith fragment and following along the longitudinal axis to the centre (Jearld 1983: fig. 16.11C). The width of each growth band was visually classified as wide, intermediate, or narrow before measurement to test the assumption that band frequency is characteristic of habitat type.

Growth was described by Model I least-squares linear regression of length-at-age and weight-at-age, calculated using the MGLH package of SYSTAT (Wilkinson 1990). Linear equations were only presented and fitted to data sets with sufficient correlated data. The ages at which longfinned eels reached threshold commercial weights in each location were estimated from weight-age regressions. The 95\% confidence limits of these estimates were calculated following Sokal \& Rohlf (1981: 498), using age-weight regressions.

Length-weight relationships were determined for longfinned eels from each location. Comparisons of condition between locations were made by using condition factors calculated for isometric growth $\left(K=10^{6} \mathrm{~W} / \mathrm{L}^{3}\right.$; where $W=$ weight in $\mathrm{g}$, and $L=$ length in mm, Bagenal 1978), to facilitate comparison between habitats.

Eel density and biomass in streams were estimated by relating the number and total weight of eels removed from the section fished to distance and area fished.

\section{RESULTS}

\section{Classification of growth bands}

Growth bands visually classified as wide, intermediate, or narrow formed clearly distinct groups of widths when measured ( $N=74$, Table 2). Growthband widths in otoliths from individual eels, visually classified as wide, intermediate, or narrow were normally distributed (Kolmogorov-Smirnov test, standardised by Lilliefors test; $P>0.3$ ), and analysis of variance showed that each group was significantly different (Tukey HSD, with Tukey-Kramer adjustment for unequal $N ; P<0.001$ ). Otolith pairs with $>80 \%$ of their growth bands visually categorised as the same width $(N=30)$ were used to derive mean band widths characteristic of growth in each of the three habitat types (e.g., Fig. 2A, B, C and F). The mean width of narrow growth bands in this group was half that of intermediate bands, and intermediate bands were half the width of wide bands (Table 3 ).

\section{Age and growth in different habitats}

\section{Relationship of length and weight to age}

Ages were determined from otoliths of 252 eels. Otoliths from a further 10 eels (4\% of total) were unreadable. Interpretation of otoliths from large longfinned eels was sometimes difficult, because growth-bands were numerous and closely spaced (e.g., Fig. 2F).

Length-age relationships of eels in different habitats showed that consistent differences in growth occurred. Longfinned eels 170-1095 mm TL ranged in age between 4 and 60 yrs. Average annual length increments, calculated from length-age relationships, ranged between 24 and $36 \mathrm{~mm}$ in pastoral streams with $N>10$, between 12 and $15 \mathrm{~mm}$ in forested

Table 2 Mean widths of growth bands visually identified as wide, intermediate, and narrow, averaged for 74 individual eels $\left(N_{1}\right)$ from habitats in the Waikato River basin. $N_{2}$, number of bands examined; CL, 95\% confidence limits; --, no data.

\begin{tabular}{|c|c|c|c|c|c|c|c|c|c|}
\hline \multirow[b]{2}{*}{ Habitat } & \multicolumn{3}{|c|}{ Wide } & \multicolumn{3}{|c|}{ Intermediate } & \multicolumn{3}{|c|}{ Narrow } \\
\hline & $N_{1}$ & $N_{2}$ & $\begin{array}{c}\text { Mean } \pm C L \\
(\mu \mathrm{m})\end{array}$ & $N_{\mathrm{I}}$ & $N_{2}$ & $\begin{array}{c}\text { Mean } \pm C L \\
(\mu \mathrm{m})\end{array}$ & $N_{1}$ & $N_{2}$ & $\begin{array}{c}\text { Mean } \pm C L \\
(\mu \mathrm{m})\end{array}$ \\
\hline Lake Karapiro & 22 & 387 & $110 \pm 6$ & 15 & 140 & $60 \pm 2$ & 9 & 123 & $23 \pm 5$ \\
\hline \multicolumn{10}{|l|}{ Pastoral streams } \\
\hline Mangahanene & 2 & 15 & $87 \pm 0$ & 5 & 105 & $56 \pm 5$ & 0 & 0 & \\
\hline Mangakara & 1 & 4 & $86 \pm 0$ & 2 & 29 & $54 \pm 9$ & 2 & 11 & $18 \pm 0$ \\
\hline Hakarimata ( 3 streams) & 12 & 59 & $88 \pm 2$ & 24 & 261 & $57 \pm 2$ & 18 & 68 & $31 \pm 0$ \\
\hline \multicolumn{10}{|l|}{ Forested streams } \\
\hline Mangakara & 6 & 34 & $77 \pm 5$ & 5 & 51 & $48 \pm 5$ & 7 & 268 & $23 \pm 2$ \\
\hline Hakarimata (3 streams) & 0 & 0 & - & 13 & 101 & $45 \pm 2$ & 14 & 388 & $25 \pm 2$ \\
\hline
\end{tabular}



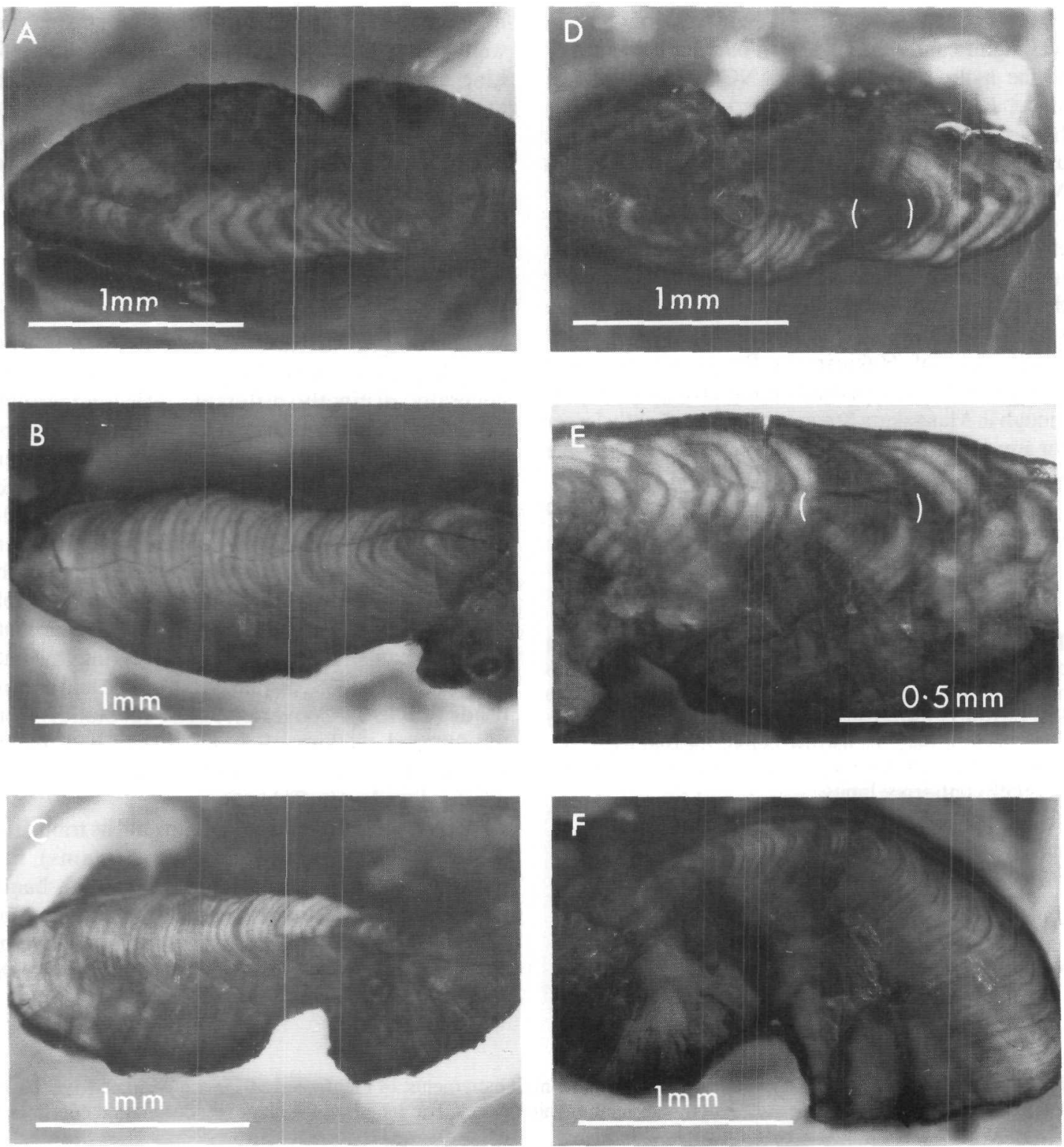

Fig. 2 Otoliths from longfinned eels (Anguilla dieffenbachii) from the Waikato River basin, North Island. Axial fracture plane shown; otoliths A-C and F have $80 \%$ of their bands of consistent width, characteristic of growth in three different habitat types: (A) Lake Karapiro eel, length $760 \mathrm{~mm}$, age 25 years; (B) Mangahanene Stream (pastoral) eel, length $662 \mathrm{~mm}$, age 43 years; (C) and (F) Mangakara Stream (forest), length 705, age 37 years, and length $915 \mathrm{~mm}$, age 53 years; (D) and (E) Lake Karapiro eel, length $830 \mathrm{~mm}$, age 30 years, with mixed band widths (bracketed section thought to be stream growth).

streams, and was $19 \mathrm{~mm}$ in both hydro-electric lakes (Table 4). The fit of data to Model I regression lines is shown in Fig. 3. Fastest growth occurred in the lowland pastoral Ahirau Stream, followed by growth in other pastoral streams. Growth of longfinned eels in forested streams was considerably slower, and growth in the hydro-electric lakes was similar to pastoral streams. 
The growth of longfinned eels in Ahirau Stream was significantly faster than in other stream sites or in the hydro-electric lakes (ANCOVA: length-age slope, $P<0.001$ ). Growth rates of longfinned eels from pastoral stream sites in the Hakarimata Ranges and in Mangapiko Stream were similar, though Mangapiko Stream eels were larger for any given age (ANCOVA: length and weight-age slope, $P>0.05$; elevation, $P<0.001$ ) (Fig. 3). Longfinned eel growth in all pastoral stream sites was considerably faster than in forested stream sites (ANCOVA: length-age slope, $P<0.001$ ). Longfinned eels from forested headwaters of Hakarimata Range streams and Mangakara Stream eels had similar slow growth rates, though in Mangakara Stream, eels were slightly larger for any given age (ANCOVA: length and weight-age slope, $P>0.05$; elevation, $P=0.003$ ).

Increase in weight with age largely reflected the increase in length with age for the same sites.

Table 3 Mean widths of annual growth bands of sagittal otoliths from 30 longfinned eels, that had more than $80 \%$ of their bands that were of similar width, in the Waikato River basin. Growth-bands were visually determined to be wide, intermediate, or narrow before measurement. $N_{1}$, number of individuals; $N_{2}$, number of bands examined; CL, $95 \%$ confidence limits.

\begin{tabular}{lrrr}
$\begin{array}{l}\text { Growth band } \\
\text { type }\end{array}$ & $N_{1}$ & $N_{2}$ & $\begin{array}{c}\text { Growth-band width, } \\
\text { mean } \pm \text { CL } \\
(\mu \mathrm{m})\end{array}$ \\
\hline Wide & 9 & 171 & $106 \pm 9$ \\
Intermediate & 10 & 193 & $55 \pm 4$ \\
Narrow & 11 & 382 & $26 \pm 2$ \\
\hline
\end{tabular}

Regression line slopes $(b)$ of pastoral stream sites were greater than for forested stream sites (Table 5). Line slopes for the hydro-electric lakes were similar to pastoral stream sites. Length-age and weight-age regressions of eels from the lakes had smaller $r^{2}$ values than pastoral streams, showing that growth was more variable in hydro-lakes than in streams (Table 4 and 5).

\section{Relation of growth-band widths to habitat-specific growth}

Widths of growth bands in otoliths of eels from pastoral streams, forested streams, and the lakes were generally distinctly different, reflecting growth variations established by length-at-age relationships. Most eel otoliths examined had a mixture of different growth-band widths, numerically dominated by bandwidths that were common amongst eels from the same location (e.g., Fig. 4). Eels from different locations, but similar habitat types, had otoliths dominated by growth-bands of similar width (Table 2). Some otoliths of eels from pastoral Hakarimata Range streams, though dominated by intermediate growth-band widths, displayed both wide and narrow bands (Table 6). Conversely, most eel otoliths from the forested sections of these streams had mainly narrow bands but also had small numbers of intermediate bands (Table 6).

Several eels from Lake Karapiro and its tributaries (Mangahanene and Mangakara Streams) had particularly high percentages of growth-bands uncharacteristic of the habitat, suggesting that long periods of growth had occurred in other habitats (e.g., Table 6). Eels from Lake Karapiro that had otoliths

Table 4 Length-age relationships, and relative annual length increments, of longfinned eels in the Waikato River basin, and Lake Matahina. $N$, sample size; length-age relationship of the form: length $=a+b$ age; $r^{2}$, correlation coefficient; CL, $95 \%$ confidence limits; $P$ for all models $<0.001$.

\begin{tabular}{|c|c|c|c|c|c|c|c|}
\hline Habitat & $N$ & $\begin{array}{l}\text { Length range } \\
\text { (mm) }\end{array}$ & $\begin{array}{c}\text { Age range } \\
\text { (yr) }\end{array}$ & $a$ & $b \pm \mathrm{SE}$ & $r^{2}$ & $\begin{array}{l}\text { Annual length } \\
\text { increment } \pm \mathrm{CL} \\
(\mathrm{mm})\end{array}$ \\
\hline \multicolumn{8}{|l|}{ Pastoral streams } \\
\hline Ahirau & 29 & $231-1095$ & $4-25$ & 58.7 & $35.8 \pm 3.5$ & 0.80 & $36 \pm 7.2$ \\
\hline Hakarimata (3 streams) & 53 & $200-1055$ & $7-39$ & 27.7 & $24.1 \pm 1.3$ & 0.88 & $24 \pm 2.6$ \\
\hline Mangapiko & 30 & $521-1086$ & $14-33$ & 150.6 & $25.1 \pm 0.9$ & 0.87 & $25 \pm 1.8$ \\
\hline \multicolumn{8}{|l|}{ Forested streams } \\
\hline Hakarimata ( 3 streams) & 22 & $320-1080$ & $18-60$ & 68.2 & $14.7 \pm 1.3$ & 0.86 & $15 \pm 2.7$ \\
\hline Mangakara & 11 & $568-915$ & $27-53$ & 249.9 & $11.9 \pm 1.1$ & 0.93 & $12 \pm 2.5$ \\
\hline \multicolumn{8}{|l|}{ Hydro-electric lakes } \\
\hline Lake Karapiro & 62 & $345-980$ & $6-30$ & 318.7 & $19.4 \pm 2.2$ & 0.57 & $19 \pm 4.4$ \\
\hline Lake Matahina & 22 & $398-960$ & $15-40$ & 190.7 & $18.8 \pm 3.4$ & 0.62 & $19 \pm 7.1$ \\
\hline
\end{tabular}



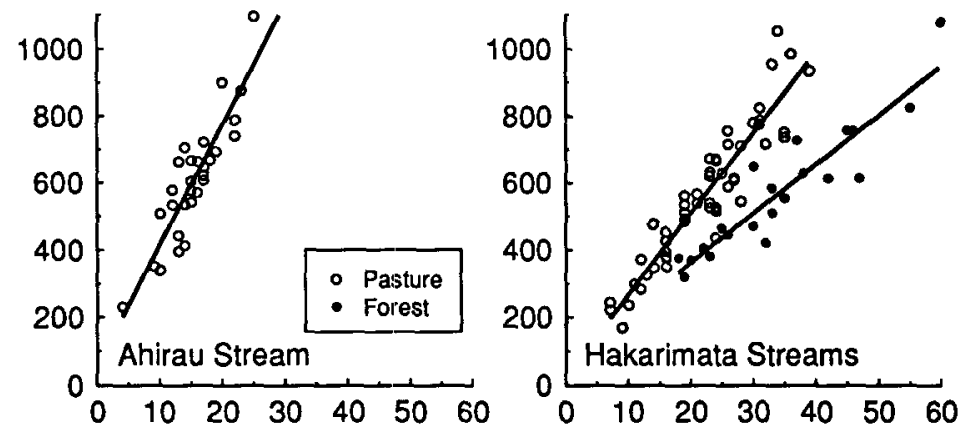

Fig. 3 Length-age relationships of longfinned eels in pastoral and forested streams, and Lake Karaprio, in the Waikato River basin, and in Lake Matahina, Rangitaiki River, North Island.
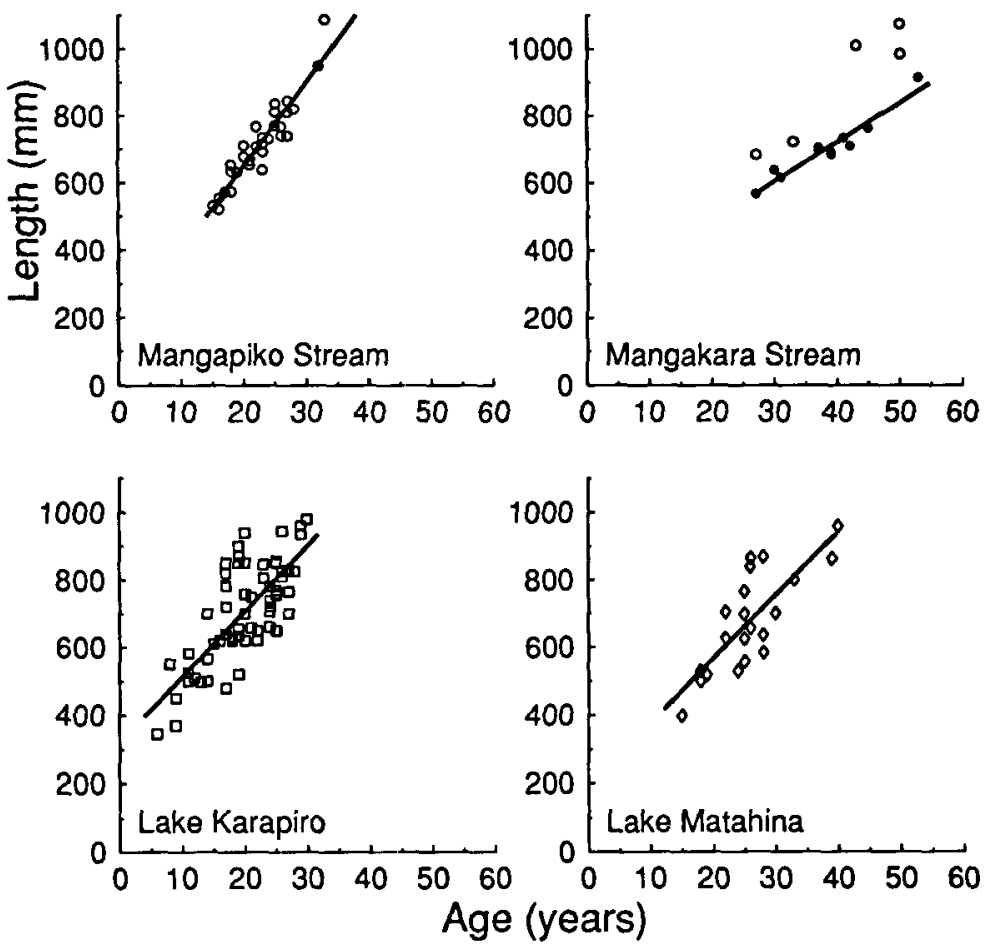

with more than $55 \%$ of their growth-bands uncharacteristic of lake growth $(N=8$, e.g., Fig. 2D and $\mathrm{E}$ ), were excluded from regression calculations (Tables 4 and 5), and from the plots of length-at-age (Fig. 3).

\section{Length-weight relationships and condition}

Length-weight relationships (Table 7) were compared between locations using condition factors (CF). Condition was not correlated with length, and so comparison was made across all available data. Condition factors from each location were normally distributed and mean CF did not vary significantly between locations (Tukey HSD tests, $P>0.05$, Table 7). The mean CF ( $\pm 95 \% \mathrm{CL}$ ) for all longfinned eels sampled was $2.63 \pm 0.09$.

\section{Eel density and biomass in Waikato River tributaries}

Total eel biomass was greater at pastoral sites than at forested sites, generally reflecting densities (Table 8). Biomass was also related to channel gradient and proportion of pool habitat (Fig. 5A and B). The inverse relation of proportion of pool habitat to gradient appears to be the factor controlling eel biomass (Fig, 5C), and pastoral sites had lower 


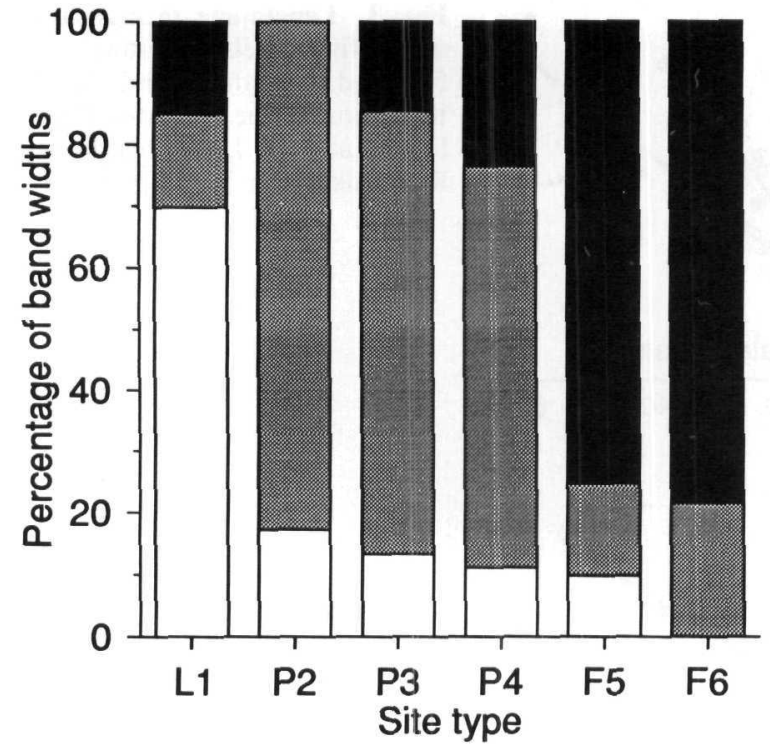

Fig. 4 Proportions of wide (white), intermediate (grey), and narrow (black) growth bands in otoliths of longfinned eels in Waikato streams, and Lake Karapiro. L1, Lake Karapiro $(N=22)$; P2, Mangahanene (pasture, $N=5$ ); P3, Hakarimata Range streams (pasture, $N=24$ ); P4, Mangakara (pasture, $N=2$ ); F5, Mangakara (forest, $N=7$ ); F6, Hakarimata Range streams (forest, $N=14$ ).

gradient than forested sites. Shortfinned eel biomass was also greatest in lowland sites (Table 8).

Forested sites had low eel biomass, but Hakarimata Range streams had double the biomass of Mangakara Stream (Table 8) despite eels from these streams having similar growth rates (Table 4). The Mangakara Stream site had a higher gradient and much lower percentage of pool habitat available (Table 1).

\section{Eel fishery management}

Age at maturity

Reproductive maturity in Anguilla species is considered to be related to length (Tesch 1977). Longfinned males migrate to sea at $50-70 \mathrm{~cm}$, and females at $>80 \mathrm{~cm}$ (Todd 1980; Jellyman \& Todd 1982). Age at maturity was estimated for longfinned eels in the present study from length-age regressions, ignoring possible differences in growth rates between sexes (Table 4). Estimates varied with growth rates from each location, and ranged between 12 and 45 years for males and from $\geq 22$ to $\geq 48$ years for females (Table 9).

\section{Commercial threshold}

Habitat-specific differences in growth have implications for management of the Waikato eel fishery. Entry of eels into the commercial fishery is governed by weight, which is nationally set at a lower limit of $150 \mathrm{~g}$, with the single exception of Lake Ellesmere. However, variation in growth means that eels of a given size from different habitats will have different ages. Weight-age relationships (Table 5) were used to estimate age at marketable size, and at a possible new weight restriction (220 and $250 \mathrm{~g}$ respectively, Table 9). Age at which longfinned eels were estimated to reach $220 \mathrm{~g}$ ranged from 7 to 19 years in hydro-electric lakes and pastoral streams, to 26 years in forested Hakarimata Range streams (Table 9). The low age estimate of 7 years for $220 \mathrm{~g}$ longfinned eels from the forested section of Mangakara Stream is probably the result of fast growth in Lake Karapiro before movement into the stream. Longfinned eels from forested sites attained a weight of $1500 \mathrm{~g}$ at the age of 48 years (Table 9), but attained this size at 26-31 years in hydro-electric lakes.

Table 5 Weight-age relationships of longfinned eels in the Waikato River basin, and Lake Matahina. $N$, sample size; weight-age relationship form of $\ln W=a+b$ age; $W$, weight in $g ; r^{2}$, correlation coefficient; $P$ for all models $<0.001$. Age range as for Table 3 .

\begin{tabular}{lrrrrr}
\hline Habitat & $N$ & Weight range (g) & $a$ & $b \pm S E$ & $r^{2}$ \\
\hline Pastoral streams & & & & & \\
Ahirau & 29 & $25-4191$ & 3.05 & $0.21 \pm 0.02$ & 0.81 \\
Hakarimata (3 streams) & 53 & $7-3650$ & 2.39 & $0.16 \pm 0.01$ & 0.86 \\
Mangapiko & 30 & $366-3581$ & 4.52 & $0.10 \pm 0.01$ & 0.78 \\
$\begin{array}{l}\text { Forested streams } \\
\text { Hakarimata (3 streams) }\end{array}$ & 22 & & & & \\
Mangakara & 11 & $89-3765$ & 3.30 & $0.08 \pm 0.01$ & 0.87 \\
Hydro-electric lakes & & & 5.07 & $0.05 \pm 0.01$ & 0.83 \\
Lake Karapiro & 62 & $80-2910$ & 4.63 & $0.10 \pm 0.01$ & 0.59 \\
Lake Matahina & 22 & $120-2400$ & 4.18 & $0.10 \pm 0.02$ & 0.66 \\
\hline
\end{tabular}




\section{DISCUSSION}

\section{Age validation}

Conclusive evidence that transparent zones in otoliths clo represent annual growth checks has been provided for several anguillid species, e.g., A. australis (Jellyman 1979), A. rostrata (Helfman et al. 1984a, 1984b), A. mossambica (McEwan \& Hecht 1984), and A. anguilla (Berg 1985; Dekker 1986; Aprahamian 1987; Vollestad \& Naesje 1988). Evidence that transparent zones are formed annually in otoliths of longfinned eels ( $A$. dieffenbachii) has been provided by three studies. In a mark/recapture study of New Zealand eels in three Canterbury streams, annual length increments in recaptured, marked longfinned eels concurred with growth estimated from otolith-determined ages and length (Burnet 1969). In Lake Pounui (lower North Island), annual length increments from a large number of tagged longfinned eels were in overall agreement with growth estimated from otolith-determined ages (D. Jellyman unpubl. data). In a mark-recapture study in the pastoral Ahirau Stream (present study), the number of transparent zones following fluorescent labels (tetracycline) on the otoliths of tagged recaptured longfinned and shortfinned eels corresponded to the number of years these eels were at liberty (Chisnall \& Kalish 1993).

\section{Growth in different habitats}

Causes of variable growth rates

New Zealand eels move upstream for several years as elvers and juveniles, documented as successive summer migrations (Jellyman 1977). Afterwards, eels are likely to live in specific areas, usually with limited home ranges (Burnet 1969; Jellyman \& Todd 1982; Chisnall 1987; Chisnall \& Kalish 1993). Growth

Table 6 Numbers of individual longfinned eels and proportions of wide, intermediate (int.), or narrow growth-band widths, in habitats of the Waikato River basin. $N$, total number of eels examined.

\begin{tabular}{|c|c|c|c|c|c|c|c|c|c|c|}
\hline \multirow[b]{3}{*}{ Habitat } & \multirow[b]{3}{*}{$N$} & \multicolumn{9}{|c|}{ Proportions of growth bands } \\
\hline & & \multicolumn{3}{|c|}{$>60 \%$} & \multicolumn{3}{|c|}{$30-60 \%$} & \multicolumn{3}{|c|}{$<30 \%$} \\
\hline & & Wide & Int. & Narrow & Wide & Int. & Narrow & Wide & Int. & Narrow \\
\hline Lake Karapiro & 22 & 14 & 1 & & 6 & 3 & 6 & 2 & 11 & 3 \\
\hline $\begin{array}{l}\text { Pastoral streams } \\
\text { Mangahanene } \\
\text { Mangakara } \\
\text { Hakarimata (3 streams) }\end{array}$ & $\begin{array}{r}5 \\
2 \\
24\end{array}$ & $\begin{array}{l}1 \\
- \\
-\end{array}$ & $\begin{array}{r}4 \\
2 \\
20\end{array}$ & $\overline{-}$ & $\overline{-}$ & $\frac{1}{3}$ & $\overline{1}$ & $\begin{array}{l}1 \\
1 \\
-\end{array}$ & $\overline{15}$ & $\overline{1}$ \\
\hline $\begin{array}{l}\text { Forested streams } \\
\text { Mangakara } \\
\text { Hakarimata ( } 3 \text { streams) }\end{array}$ & $\begin{array}{r}7 \\
14\end{array}$ & - & - & $\begin{array}{r}7 \\
12\end{array}$ & - & - & $\overline{2}$ & $\begin{array}{l}6 \\
-\end{array}$ & $\begin{array}{r}5 \\
10\end{array}$ & - \\
\hline
\end{tabular}

Table 7 Weight-length relationships of longfinned eels in the Waikato River basin, and in Lake Matahina. $N$, sample size; weight-length relationship in the form of $\ln W=\ln a+b \ln L ; W$, weight in g; $L$, length in $\mathrm{mm}, r^{2}$, correlation coefficient; $\mathrm{CF}$, condition factor; CL, $95 \%$ confidence limits; length ranges as for Table 3 ; weight ranges as for Table $4 ; P$ for all models $<0.001$.

\begin{tabular}{lccccc}
\hline Habitat & $N$ & $a$ & $b \pm \mathrm{SE}$ & $r^{2}$ & $\mathrm{CF} \pm \mathrm{CL}$ \\
\hline Pastoral streams & & & & & \\
Ahirau & 33 & -14.38 & $3.25 \pm 0.07$ & 0.99 & $2.74 \pm 0.15$ \\
Hakarimata (3 streams) & 53 & -14.45 & $3.25 \pm 0.05$ & 0.99 & $2.48 \pm 0.12$ \\
Mangapiko & 30 & -11.99 & $2.86 \pm 0.25$ & 0.83 & $2.57 \pm 0.17$ \\
Forested streams & & & & & \\
Hakarimata (3 streams) & 22 & -13.93 & $3.17 \pm 0.13$ & 0.97 & $2.72 \pm 0.28$ \\
Mangakara & 11 & -10.99 & $2.72 \pm 0.43$ & 0.82 & $2.76 \pm 0.27$ \\
Hydro-electric lakes & & & & & \\
Lake Karapiro & 65 & -13.72 & $3.12 \pm 0.17$ & 0.85 & $2.51 \pm 0.12$ \\
Lake Matahina & 22 & -13.89 & $3.17 \pm 0.02$ & 0.95 & $2.76 \pm 0.10$ \\
\hline
\end{tabular}



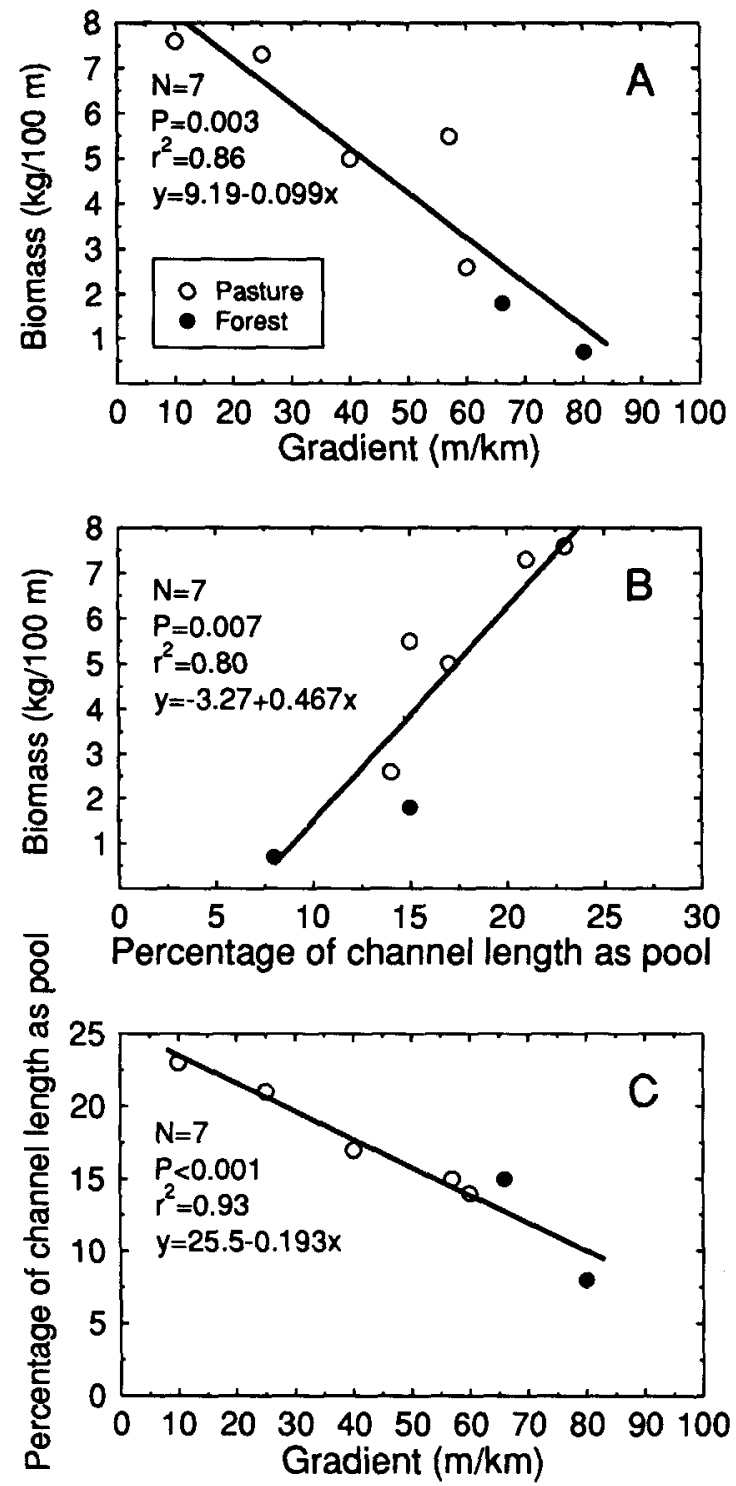

Fig.5 Association of eel biomass with A, gradient; $\mathbf{B}$, percentage of channel as pool habitat; $\mathbf{C}$, relationship of pool habitat to channel gradient.

bands in otoliths appear to reflect this limited movement by showing uniform widths characteristic of different habitats.

Water temperature is probably the most important factor causing habitat-specific growth differences in longfinned eels. Low water temperatures are well known to reduce eel mobility and lower growth rates (e.g., Cairns 1942; Sinha \& Jones 1967; Nyman
1972; Ryan 1984; Chisnall 1989). In addition, increased light available to pastoral streams, and the generally higher trophic status of lakes, may allow greater food production in these habitats than in forested streams.

Most eels examined had two or more concentric areas in their otoliths with different widths of growth bands. It is likely that growth in two or more habitats caused this variation in band width, because the majority of eels from any particular habitat had $>60 \%$ of their rings of one type (Table 2 and 6, Fig. 2). Eighteen longfinned eels from pastoral stream sites below forest in the Hakarimata Range had occasional series of narrow growth-bands on their otoliths, suggesting that some growth had occurred in forested habitat (e.g., Fig. 2D and E). Conversely, most longfinned eels from forested sections of these streams had some series of intermediate width growth-bands on their otoliths, but always $<30 \%$, suggesting that some growth had taken place in pastoral stream or river habitat during passage through the lower catchment. Sloane (1984) also recognised this phenomenon when he found several closely spaced rings surrounded by a few broadly spaced rings on otoliths from $A$. australis in Tasmania. He interpreted the different ring series as representing slow growth in the Clyde River followed by a number of years of faster growth in headwater lakes.

\section{Hydro-electric lakes}

The greater size at age of most longfinned eels from Lake Karapiro than at other study sites is probably related to low eel densities in the lake and its eutrophic nutrient status (Livingston et al. 1986). Eels may also expend less energy in lake environments compared with eels in streams. Recruitment has been restricted to the Waikato River above Karapiro since completion of the Karapiro hydro-electric dam in 1947. Growth rates of longfinned eels are also high in Lake Matahina on the Rangitaiki River where recruitment has been restricted and the remnant eel population is small (Chisnall \& Hayes 1991).

As longfinned eels grow larger, they may become mainly piscivorous, and can be voracious cannibals (Cairns 1942; Jellyman 1989). The high energy content of fish promotes fast growth (e.g., Ryan 1982). The lack of eels smaller than $500 \mathrm{~mm}$ in the samples from Lake Karapiro, and in two of its tributaries (Mangahanene and Mangakara Streams), may be evidence of cannibalism. Elvers are known to successfully climb the Karapiro dam and enter the lake (e.g., Jellyman \& Todd 1982), yet only three 
eels $<500 \mathrm{~mm}$ were caught. Predation of small eels during trapping may have contributed to this effect but cannot explain the lack of small eels caught during exhaustive electro-fishing of the two tributaries (Mangahanene and Mangakara Streams). A similar conclusion was drawn by J. Boubée (pers. comm.) after repeated sampling of Lake Matahina in 1989, when less than $7 \%$ of his catches were eels smaller than $500 \mathrm{~mm}$ in length. Eels caught in Mangapiko Stream, above Lake Waikare (this study) were also greater than $500 \mathrm{~mm}$ in length.

Variability of longfinned eel growth in both Lakes Karapiro and Matahina was probably due to the congregation of eels from different habitats as a consequence of lake level lowering. The inclusion of some eels that had probably grown mostly in pastoral and forested streams added to growth variability.

\section{Pastoral streams}

The fast to moderate growth rates of longfinned eels in pastoral streams are likely to be influenced by several important factors which may include: water temperature, high food abundance (Taylor 1988; Quinn \& Hickey 1990), low gradients that cause low water velocities and a high proportion of pool habitat, intraspecific competition, and interspecific competition with shortfinned eels.

The most important factor contributing to the faster growth of longfinned eels in the lowland Ahirau Stream compared with other pastoral streams was

Table 8 Eel density and biomass in streams of the Waikato River basin. LF, longfinned eel; SF, shortfinned eel.

\begin{tabular}{|c|c|c|c|c|c|c|c|c|c|c|}
\hline \multirow[b]{3}{*}{ Habitat } & \multirow{2}{*}{\multicolumn{4}{|c|}{$\begin{array}{c}\text { Eel density } \\
\text { number }(100 \mathrm{~m})^{-1}\end{array}$}} & \multicolumn{6}{|c|}{ Eel biomass } \\
\hline & & & & & \multicolumn{3}{|c|}{$\mathrm{kg}(100 \mathrm{~m})^{-1}$} & \multicolumn{3}{|c|}{$\mathrm{kg} \mathrm{ha}^{-1}$} \\
\hline & $\% \mathrm{LF}$ & $\mathbf{L F}$ & SF & Total & LF & SF & Total & LF & SF & Total \\
\hline $\begin{array}{l}\text { Lowland pasture } \\
\text { Mangahanene } \\
\text { Ahirau }\end{array}$ & $\begin{array}{l}37 \\
23\end{array}$ & $\begin{array}{l}2.5 \\
6.3\end{array}$ & $\begin{array}{r}4.3 \\
21.3\end{array}$ & $\begin{array}{r}6.8 \\
27.6\end{array}$ & $\begin{array}{l}3.3 \\
5.5\end{array}$ & $\begin{array}{l}4.3 \\
1.8\end{array}$ & $\begin{array}{l}7.6 \\
7.3\end{array}$ & $\begin{array}{l}133.6 \\
391.7\end{array}$ & $\begin{array}{l}171.1 \\
127.6\end{array}$ & $\begin{array}{l}304.7 \\
519.3\end{array}$ \\
\hline $\begin{array}{l}\text { Pasture below forest } \\
\text { Hakarimata ( } 3 \text { streams) } \\
\text { Mangapiko } \\
\text { Mangakara }\end{array}$ & $\begin{array}{r}66 \\
81 \\
100\end{array}$ & $\begin{array}{l}7.1 \\
7.8 \\
2.5\end{array}$ & $\begin{array}{l}3.7 \\
1.8 \\
-\end{array}$ & $\begin{array}{r}10.8 \\
9.6 \\
2.5\end{array}$ & $\begin{array}{l}4.6 \\
4.6 \\
2.6\end{array}$ & $\begin{array}{l}0.4 \\
0.9 \\
-\end{array}$ & $\begin{array}{l}5.0 \\
5.5 \\
2.6\end{array}$ & $\begin{array}{l}329.4 \\
217.0 \\
129.0\end{array}$ & $\begin{array}{c}31.1 \\
42.3 \\
-\end{array}$ & $\begin{array}{l}360.5 \\
259.3 \\
129.0\end{array}$ \\
\hline $\begin{array}{l}\text { Indigenous forest } \\
\text { Hakarimata ( } 3 \text { streams) } \\
\text { Mangakara }\end{array}$ & $\begin{array}{l}100 \\
100\end{array}$ & $\begin{array}{l}2.7 \\
1.1\end{array}$ & - & $\begin{array}{l}2.7 \\
1.1\end{array}$ & $\begin{array}{l}1.8 \\
1.1\end{array}$ & - & $\begin{array}{l}1.8 \\
1.1\end{array}$ & $\begin{array}{r}107.4 \\
54.3\end{array}$ & - & $\begin{array}{r}107.4 \\
54.3\end{array}$ \\
\hline
\end{tabular}

Table 9 Freshwater age of longfinned eels in the Waikato River basin and in Lake Matahina at commercial threshold weights, and at $1500 \mathrm{~g}$, estimated from weight-age regressions (Table 4). Age at maturity estimated from Model I length-age regressions (Table 3) (male 50-70 cm, and female $>80 \mathrm{~cm}$, Todd 1980). CL, 95\% confidence limits using age-weight regressions (Sokal \& Rohlf 1981).

\begin{tabular}{|c|c|c|c|c|c|c|}
\hline \multirow[b]{2}{*}{ Habitat } & \multicolumn{4}{|c|}{$\begin{array}{l}\text { Age in years at specific weights } \\
\text { (CL in brackets) }\end{array}$} & \multicolumn{2}{|c|}{$\begin{array}{l}\text { Age at maturity } \\
\text { (years) }\end{array}$} \\
\hline & & $220 \mathrm{~g}$ & $250 \mathrm{~g}$ & $1500 \mathrm{~g}$ & Male & Female \\
\hline $\begin{array}{l}\text { Pastoral streams } \\
\text { Ahirau } \\
\text { Hakarimata ( } 3 \text { streams) } \\
\text { Mangapiko }\end{array}$ & $\begin{array}{r}11 \\
19 \\
9\end{array}$ & $\begin{array}{l}(4-14) \\
(8-22) \\
(0-13)\end{array}$ & $\begin{array}{ll}12 & (5-14) \\
20 & (9-23) \\
10 & (1-14)\end{array}$ & $\begin{array}{ll}20 & (14-23) \\
32 & (21-34) \\
28 & (21-32)\end{array}$ & $\begin{array}{l}12-18 \\
20-30 \\
15-21\end{array}$ & $\begin{array}{l}\geq 22 \\
\geq 33 \\
\geq 26\end{array}$ \\
\hline $\begin{array}{l}\text { Forested streams } \\
\text { Hakarimata ( } 3 \text { streams) } \\
\text { Mangakara }\end{array}$ & $\begin{array}{r}26 \\
7\end{array}$ & $\begin{array}{l}(9-29) \\
(0-18)\end{array}$ & $\begin{array}{l}28(11-31) \\
10(0-20)\end{array}$ & $\begin{array}{ll}50 & (34-54) \\
49 & (38-59)\end{array}$ & $\begin{array}{l}30-45 \\
22-38\end{array}$ & $\begin{array}{l}\geq 48 \\
\geq 48\end{array}$ \\
\hline $\begin{array}{l}\text { Hydro-electric lakes } \\
\text { Lake Karapiro } \\
\text { Lake Matahina }\end{array}$ & $\begin{array}{r}7 \\
12 \\
\end{array}$ & $\begin{array}{l}(0-15) \\
(0-21)\end{array}$ & $\begin{array}{r}9(0-16) \\
13(0-22) \\
\end{array}$ & $\begin{array}{ll}26 & (14-34) \\
31 & (20-41) \\
\end{array}$ & $\begin{array}{l}10-20 \\
16-27\end{array}$ & $\begin{array}{l}\geq 22 \\
\geq 32 \\
\end{array}$ \\
\hline
\end{tabular}


probably predation on the large number of small shortfinned eels present there. Ahirau Stream sustained almost twice the biomass of longfinned eels than did lowland Mangahanene Stream which had similar numbers and biomass of both eel species (Table 8), and few small eels.

Intraspecific and interspecific competition among large individuals of both eel species in Mangahanene Stream may have been responsible for the relatively lower growth rate of longfinned eels there. Territoriality and antagonistic behaviour of large eels is documented by several authors (e.g., Ford \& Mercer 1986; Knights 1987), and growth rates are consequently promoted or inhibited. Both eel species (mostly large individuals) caught in Mangahanene Stream were evenly distributed throughout the stream section sampled. Conversely, in the Ahirau Stream, large longfinned eels dominated the population and occupied the pools (more productive habitat), whereas shortfinned eels (mostly small individuals) were only caught in the runs and riffles.

Pasture has been shown to provide terrestrial invertebrates to fish in streams during floods (Mitchell 1984; Rounick \& Hicks 1985; Chisnall 1987; Jellyman 1991). Eels in lowland pastoral streams are more likely to have access to terrestrial invertebrates than eels in pastoral streams immediately below forest where gradients are high and the flood plain is narrower. Terrestrial invertebrates can make a significant contribution to the diet of longfinned eels (Cairns 1942; Burnet 1952; Chisnall 1987; Jellyman 1989). Longfinned eels have also been shown to consume more terrestrial prey when available than common aquatic food species (Chisnall 1987).

Slower growth of longfinned eels in pasture below forest (Hakarimata Range streams and Mangapiko Stream) than in the lowland Ahirau Stream, is also likely to be associated with reduced availability of pool habitat (Fig. 5). Limited foraging area for large eels, along with reduced productivity in fewer and smaller pools, may contribute to reduced eel growth.

The large Y-intercepts of growth models for longfinned eels in both forested and pastoral sections of Mangakara Stream, and in pastoral Mangapiko Stream (Tables 4 and 5) may be explained by the fast growth of juvenile eels en route to these streams. Fast growth of juveniles is indicated by the young ages at which longfinned eels attain the threshold commercial weight $(220 \mathrm{~g}$ ) in both streams ( 7 to 9 years, Table 9 ). Wide growth-band widths that were found in otoliths of longfinned eels from Mangakara Stream are consistent with fast growth as juveniles in Lake Karapiro (Table 2).
Annual length increments of longfinned eels estimated from otolith-determined ages in the present study (12-36 mm, Table 3 ) were similar to increments in tagged longfinned eels in three pastoral Canterbury streams (Burnet 1969). Burnet measured annual increments that averaged 10-20 mm for longfinned eels $350-800 \mathrm{~mm}$ in length. In addition, two large longfinned eels recaptured after 10 years from the same streams had grown $25 \mathrm{~mm}$ and $28 \mathrm{~mm}$ in length annually (Burnet 1969).

The reduction in catch of shortfinned eels with increased gradients (Table 1 and 8 ) is consistent with the known distribution of the species, which is predominantly lowland (e.g., Jellyman \& Todd 1982). Longfinned eels prefer water with high dissolved oxygen concentrations, are capable climbers, and are therefore frequently found in upstream reaches (Cairns 1941; Jellyman 1977, 1989; Jellyman \& Todd 1982).

\section{Forested streams}

Low growth rates and narrow growth-band widths on otoliths of longfinned eels from forested streams may be attributable to low water temperatures, low food abundance, fast water velocities associated with high gradients, limited pool habitat, and possibly interspecific competition. Water temperatures in streams in native forest in the Waikato region do not rise much above $14^{\circ} \mathrm{C}$ throughout the year (e.g., S. Hanchet, MAF Fisheries, Wellington, unpubl. data; J. Rutherford, NIWA Ecosystems, Hamilton, unpubl. data). The response of longfinned eels to low water temperatures in forested streams has not been studied, but slow growth is a probable consequence. Catches of both New Zealand eel species in the Waikato River have been shown to reduce when water temperatures drop below $14^{\circ} \mathrm{C}$ (Chisnall 1987), and longfinned eels are thought to reduce or stop feeding when water temperatures are below $7-8^{\circ} \mathrm{C}$ (Burnet 1955). Other studies of both shortfinned and longfinned eels indicate that cessation of feeding occurs when water temperatures fall below $5-6^{\circ} \mathrm{C}$ (Woods 1964; Jellyman 1991). It is also well known that narrow otolith increments are produced at lower water temperatures (e.g., Umezawa \& Tsukamato 1991).

Streams in native forest have lower food availability than pastoral streams because fish and invertebrate biomass may be low (Taylor 1988; Hanchet 1990; Quinn \& Hickey 1990), and vegetation inhibits overland run-off. Low abundance of fish in upper catchments probably limits piscivory by longfinned eels, and could impair growth compared with lower catchments where fish are more plentiful. 
The macroinvertebrate biomass is significantly reduced with increased gradient in New Zealand streams (Quinn \& Hickey 1990). Invertebrates are important food for longfinned eels (Cairns 1942; Burnet 1952; Chisnall 1987; Jellyman 1989). Freshwater crayfish (koura, Paranephrops planifrons) are usually the most abundant prey species present in forested streams in the Waikato region (S. Hanchet, unpubl. data). Koura are also the most common food item found in longfinned eel stomachs in forested streams (B.L.C. pers. obs.). In eel removal experiments (Hanchet \& Chisnall 1991), koura densities increased markedly after eels were removed from two pastoral streams below forest.

Reduced pool habitat in higher gradients of forested streams restricts the foraging area for longfinned eels, and appears to limit density to about one eel per pool. Higher gradients may also cause longfinned eels to expend more energy to maintain their position against faster flows, further restricting growth. Galaxid species occur in forested streams, generally at low densities (Hanchet 1990), and where present together with longfinned eels must increase competition for food.

\section{Comparative growth rates}

Growth rates of longfinned eels in pastoral streams were considerably faster than growth rates for coexisting shortfinned eels. In the Ahirau Stream, annual incremental growth of longfinned eels was 36 $\mathrm{mm}$, whereas for shortfinned eels it was $18 \mathrm{~mm}$ (length $=110.4+21.9$ age, $r^{2}=0.63, N=95$, ages 518 years, B.L.C. unpubl. data). Longfinned eels from Hakarimata Range streams also grew faster than shortfinned eels; incremental growth was $24 \mathrm{~mm}$ (this study) and $16 \mathrm{~mm}$ (Chisnall \& Hayes 1991), respectively .

Growth of longfinned eels in unexploited streams in the present study (25-36 mm, Table 4) was generally faster than that found in an exploited population in the lower Waikato River. In the exploited population, longfinned eels smaller than $500 \mathrm{~mm}$ had relative annual increments of between 15 and $17 \mathrm{~mm}$ (ages 5-20 years, Chisnall 1989). This difference in growth is not necessarily caused by exploitation and may be entirely an effect of habitat differences. However, intensive commercial fishing, which removes large eels, is thought to cause the high densities of small eels observed in the backwaters of the Waikato River and result in slow growth (Chisnall 1989).

The relatively fast growth rates observed for eels from the hydro-electric lakes Karapiro and Matahina were considerably slower than attained by $A$. nebulosa labiata in Lake Kariba, Zambia (Balon 1975). The average annual length increment found by Balon was $77 \mathrm{~mm}$. This rapid growth was similar to that attained by longfinned eels in the hydro-electric Lake Aniwhenua on the Rangitaiki River (upstream of Lake Matahina, Mitchell \& Chisnall 1992).

Annual length increments determined for longfinned eels in the present study $(12-36 \mathrm{~mm})$ are slightly lower than those obtained for both European eels (A. anguilla 20-46 mm: Dekker 1986) and American eels (A. rostrata 34-62 mm: Hurley 1972; Helfman et al. 1984a, 1984b).

\section{Biomass}

Eel biomass in unexploited streams of the Waikato River basin has apparently changed little in 40 years. The yield from lowland pastoral Ahirau Stream (519 $\mathrm{kg} \mathrm{ha}^{-1}$, Table 8), was similar to the $578 \mathrm{~kg} \mathrm{ha}^{-1}$ yield estimate of longfinned eels reported by Burnet (1952) in nearby lowland pastoral Kaniwhaniwha Stream. Biomass estimates in other pastoral streams (129$361 \mathrm{~kg} \mathrm{ha}^{-1}$ ) were generally similar to catches in the upper Waipa River (308 $\mathrm{kg} \mathrm{ha}^{-1}$, Burnet 1952). The yield from forested Hakarimata Range streams and Mangakara Stream (107 and $36 \mathrm{~kg} \mathrm{ha}^{-1}$ ) was also similar to the estimate of $62 \mathrm{~kg} \mathrm{ha}^{-1}$ in the forested Ngakoaohia Stream (Burnet 1952). These similarities are surprising given the considerable commercial exploitation that eel populations have undergone during the last 4 decades. This may imply that recruitment levels have remained relatively constant.

\section{Management implications}

The relatively fast growth rates achieved by longfinned eels in Lakes Karapiro and Matahina suggest a method by which the commercial fishery and possibly potential breeding stocks could be enhanced. Improved access of eels into hydro-impoundments by construction of elver passes over dams throughout the country (e.g., Mitchell 1990; Mitchell \& Boubée 1990), may provide highly productive new fisheries. In addition, if downstream passage from these lakes was provided for mature eels, longfinned eel breeding stocks may also be enhanced.

Hydro-electric impoundments in New Zealand rivers are generally considerable distances upstream from the sea, and have low population densities of land-locked eels, making them well suited for the production of female longfinned eels. Over $50 \%$ of longfinned eels caught in Lakes Karapiro and Matahina were larger than $750 \mathrm{~mm}$ and within the 
size range of mature females (Todd 1980; Jellyman \& Todd 1982). There is evidence from work on A. anguilla that the proportion of females in an eel population increases with distance upstream (Aprahamian 1988). Occurrence of females in an eel population is also high if population density is low (Rossi \& Colombo 1979; Colombo et al. 1984). The selective production of female eels in the hydro-lakes is nationally important for the fishery because commercial fishing pressure tends to selectively remove females from the population.

The considerable age of females from forested streams ( $\geq 48$ years) has particular significance in terms of production from reserve areas. To maintain breeding stocks of longfinned eels, reserve areas (where commercial fishing is prohibited) are advocated to ultimately ensure recruitment of juveniles throughout New Zealand (Todd 1981; Todd \& Dodgshun 1982). Almost all such areas are under indigenous forest (such as in national parks and scenic reserves), and are removed from the coast. Most rivers flowing from these reserve areas are likely to be exposed to commercial fishing pressure in their lowland reaches. There is clearly a need for protection of longfinned eel females as they migrate from reserve areas. This could best be accomplished by imposing an upper size restriction on the commercial fishery (e.g., $1500 \mathrm{~g}$, Table 9). The particularly slow growth of eels from these areas, causing considerable time lags between generations, makes conservation of such stocks important.

\section{ACKNOWLEDGMENTS}

Special thanks to Stuart Hanchet (MAF Fisheries, Wellington) for help in taking large eels from rugged bush sites, and for encouragement. Appreciation for other field assistance is expressed to Dean Tully, David West (University of Waikato, 1989), Jacques Boubée, John Ingram, Ian Kusabs (MAF Fisheries, Hamilton) and Bob van Boven (MAF Fisheries, Rotorua). We also thank Don Jellyman (MAF Fisheries, Christchurch) for constructive criticism of the manuscript. Two anonymous referees also helped clarify the text.

\section{REFERENCES}

Aprahamian, M. W. 1987: Use of the burning technique for age determination in eels (Anguilla $(\mathrm{L}$.$) ) derived$ from the stocking of elvers. Fisheries research 6: 93-96.

Aprahamian, M. W. 1988: Age structure of eel, Anguilla (L.), populations in the River Severn, England, and the River Dee, Wales. Aquaculture and fisheries management 19: 365-376.
Bagenal, T. 1978: Methods for assessment of fish production in fresh waters. 3rd ed. Oxford, Blackwell Scientific Publications. 365 p.

Balon, E. K. 1975: The eels of Lake Kariba: distribution, taxonomic status, age, growth and density. Journal of fish biology 7: 797-815.

Berg, R. 1985: Age determination of eels, Anguilla (L): comparison of field data with otolith ring patterns. Journal of fish biology 26: 537-544.

Boubée, J. A. T.; Ingram, J.; Kusabs, I. 1989: Arapuni tailrace/headrace dewatering fish operations. New Zealand freshwater fisheries miscellaneous report 18.

Burnet, A. M. R. 1952: Studies on the ecology of the New Zealand longfinned eel, Anguilla dieffenbachii Gray. Australian journal of marine and freshwater research 3: 32-63.

Burnet, A. M. R. 1955: A study on the ecology of the New Zealand freshwater eels. Unpublished MSc thesis, University of Canterbury, New Zealand. $42 \mathrm{p}$.

Burnet, A. M. R. 1969: The growth of New Zealand freshwater eels in three Canterbury streams. New Zealand joumal of marine and freshwater research 3: 376-384.

Cairns, D. 1941: Life-history of the two species of New Zealand freshwater eel. I. Taxonomy, age, growth, migration, migration and distribution. New Zealand journal of science and technology 23B: 53-72.

Cairns, D. 1942: Life history of the two species of freshwater eel in New Zealand. II. Food, and interrelationships with trout. New Zealand journal of science and technology 23B: 132-148.

Chisnall, B. L. 1987: Juvenile eel biology in the backwaters of the Waikato River. Unpublished MSc thesis, University of Waikato, New Zealand. $152 \mathrm{p}$.

Chisnall, B. L. 1989: Age, growth and condition of freshwater eels (Anguilla sp.) in backwaters of the Lower Waikato River, New Zealand. New Zealand journal of marine and freshwater research 23: 459-465.

Chisnall, B. L.; Hayes, J. W. 1991: Age and growth of shortfinned eels (Anguilla australis) in the lower Waikato basin, North Island, New Zealand. New Zealand journal of marine and freshwater research 25: 71-80.

Chisnall, B. L.; Kalish, J. 1993: Age validation and movement of freshwater eels (Anguilla dieffenbachii and A. australis) in a New Zealand pastoral stream. New Zealand journal of marine and freshwater research 27: 333-338 (this issue).

Colombo, G; Grandi, G; Rossi, R. 1984: Gonad differentiation and body growth in Anguilla L. Journal of fish biology 24: 215-228. 
Dekker, W. 1986: Age reading of European eels using tetracycline labelled otoliths. International council for the exploration of the sea C.M. 1986/M: 16 , $14 \mathrm{p}$.

Ford, T. E.; Mercer, E. 1986: Density, size distribution and home range of American eels, Anguilla rostrata, in a Massachusetts salt marsh. Environmental biology of fishes 17: 309-314.

Hanchet, S. M. 1990; Effect of land use on the distribution and abundance of native fish in tributaries of the Waikato River in the Hakarimata Range, North Island, New Zealand. New Zealand journal of marine and freshwater research 24: 159-171.

Hanchet, S. M.; Chisnall, B. L. 1991: Hakarimata Range revisited-preliminary results of eel removal experiments. Freshwater catch 47: 14-15.

Helfman, G. S.; Bozeman, E. L.; Brothers, E. B. 1984a: Size, age and sex of American eels in a Georgia River. Transactions of the American Fisheries Society 113: 132-141.

Helfman, G. S.; Bozeman, E. L.; Brothers, E. B. 1984b: Comparison of Americin eel growth rates from tag returns and length-age analysis. United States fisheries bulletin 82: 519-522

Hu, L. C.; Todd, P. R. 1981: An improved technique for preparing eel otoliths for aging. New Zealand journal of marine and freshwater research 15 : 445-446.

Hurley, D. A. 1972: The American eel (Anguilla rostrata) in eastern Lake Ontario. Journal of the Fisheries Research Board of Canada 29: 535-543.

Jearld, A., Jr. 1983: Age determination. In: Neilsen, L. A.; Johnson, D. L. ed. Fisheries techniques. American Fisheries Society, Bethesda, Maryland, pp. 301324.

Jellyman, D. J. 1977: Summer upstream migration of juvenile freshwater eels in New Zealand. New Zealand journal of marine and freshwater research 11: 61-71.

Jellyman, D. J. 1979: Scale development and age determination in New Zealand freshwater eels (Anguilla spp.). New Zealand journal of marine and freshwater research 13: 23-30.

Jellyman, D. J. 1989: Diet of two species of freshwater eel (Anguilla spp.) in Lake Pounui, New Zealand. New Zealand journal of marine and freshwater research 23: 1-10.

Jellyman, D. J. 1991: Factors affecting the activity of two species of eel (Anguilla spp.) in a small New Zealand lake. Journal of fish biology 39: 7-14.

Jellyman, D. J. 1992: Lake Ellesmere--an important fishery with an uncertain future. Freshwater catch 48 : 3-5.
Jellyman, D. J.; Todd, P. R. 1982: New Zealand freshwater eels; their biology and fishery. Fisheries Research Division, Information leaflet $11,19 \mathrm{p}$.

Knights, B. 1987: Agonistic behaviour and growth in the European eel, Anguilla L., in relation to warm water aquaculture. Journal of fish biology 31 : 265-276.

Livingston. M. E.; Biggs, B. J.; Gifford, J. S. 1986: Inventory of New Zealand lakes. Part I. North Island. Water and soil miscellaneous report 80 , Ministry of Works and Development, Wellington.

McEwan, A.; Hecht, T. 1984: Age and growth of longfin eel, Anguilla mossambica Peters, 1852 (Pisces: Anguillidae) in Transkei rivers. South African journal of zoology 19: 280-285.

Mitchell, C. P. 1984: The Lake Poukawa traditional eel fishery; problems and suggestions for a management strategy. Fisheries environmental report 49.

Mitchell, C. P. 1990: Fish passes for native fish: a guide for managers. New Zealand freshwater fisheries miscellaneous report $45,20 \mathrm{p}$.

Mitchell, C. P.; Boubée, J. A. T. 1990: Matahina elver pass study. New Zealand freshwater fisheries miscellaneous report $36,15 \mathrm{p}$.

Mitchell, C. P.; Chisnall, B. L. 1992: Problems facing migratory native fish populations in the upper Rangitaiki River system. New Zealand freshwater fisheries miscellaneous report 119, $21 \mathrm{p}$.

Nyman, L. 1972: Some effects of temperature on eel (Anguilla) behaviour. Report of the Institute of Freshwater Research Drottningholm 52: 90-102.

Phillips, C. J.; Nelson, C. S. 1981: Sedimentation in an artificial lake-Lake Matahina, Bay of Plenty. New Zealand journal of marine and freshwater research 15: 459-473.

Quinn, J. M.; Hickey, C. W. 1990: Characterisation and classification of benthic invertebrate communities in 88 New Zealand rivers in relation to environmental factors. New Zealand journal of . marine and freshwater research 24: 387-409.

Rossi, R.; Colombo, G. 1979: Some observations on age, sex and growth of silver eels (Anguilla L.) in North Adriatic lagoons. In: Thurow, F. ed. Eel research and management. Rapports et procèsverbaux des réunions, Conseil International pour l'Exploration de la Mer 174: 64-69.

Rounick, J. S.; Hicks, B. J. 1985: The stable isotope ratios of fish and their invertebrate prey in four New Zealand rivers. Freshwater biology 15: 207-214.

Ryan, P. A. 1982: Energy contents of some New Zealand freshwater animals. New Zealand joumal of marine and freshwater research 16: 283-287. 
Ryan, P. A. 1984: Diel and seasonal feeding activity of the shortfinned eel Anguilla australis schmidtii, in Lake Ellesmere Canterbury, New Zealand. Environmental biology of fishes 11: 229-234.

Sinha, V. R. P.; Jones, J. W. 1967: On the food of the freshwater eels and their feeding relationship with the salmonids. Journal of zoology, London 153: 119-137.

Sloane, R. D. 1984: Distribution, abundance, growth and food of freshwater eels (Anguilla spp.) in the Douglas River, Tasmania. Australian journal of marine and freshwater research 35: 325-339.

Sokal, R.R.; Rohlf, F.J. 1981: Biometry, the principles and practice of statistics in biological research. Second edition New York, H. Freeman and company. 859 p.

Strachan, C. 1979: The Waikato River a water resources study. Water and soil technical publication 11, $225 \mathrm{p}$.

Swales, S.; West, D. W. 1991: Distribution, abundance and conservation status of native fish in some Waikato streams in North Island, New Zealand. Journal of the Royal Society of New Zealand 21: 281-296.

Taylor M. J. 1988: Features of freshwater fish habitat in South Westland and the effect of forestry practice. New Zealand Ministry of Agriculture and Fisheries, Fisheries environmental report $97,89 \mathrm{p}$.
Tesch, F. W. 1977: The eel-biology and management of anguillid eels. London, Chapman and Hall. 434 p.

Todd, P. R. 1980: Size and age of migrating New Zealand freshwater eels (Anguilla spp.). New Zealand journal of marine and freshwater research 14: 283-293.

Todd, P. R. 1981: Timing and periodicity of migrating New Zealand freshwater eels (Anguilla spp.). New Zealand journal of marine and freshwater research 15: 225-235.

Todd, P. R.; Dodgshun, T. J. 1982: Commercial eel fishing: closed areas and maintenance of reserve breeding stocks. New Zealand MAF Fisheries internal report, $12 \mathrm{p}$.

Umezawa, A.; Tsukamoto, K. 1991: Factors affecting otolith formation in Japanese eel, Anguilla japonica T. \& S., elvers. Joumal of fish biology 39: 211-223.

Vollestad, L. A.; Naesje, T. F. 1988: Reading otoliths of eels, Anguilla (L.), of known age from Kolderveen, the Netherlands. Aquaculture and fisheries management 19: 387-391.

Wilkinson, L. 1990: SYSTAT: the system for statistics. Evanston, Illinois. SYSTAT Inc.

Woods, C. S. 1964: Fisheries aspects of the Tongiriro power development project. New Zealand fisheries technical report 10: 1-214. 